De gruyter DOI: 10.1515/plass-2017-0008

Zhimin Yin*, Krystyna Michalak, Renata Lebecka

Plant Breeding and Acclimatization Institute - National Research Institute, Młochów Research Center, 05-831 Młochów, Platanowa 19 Str. Poland;

*Corresponding author: z.yin@ihar.edu.pl

\title{
COLLECTION OF POTATO VIRAL PATHOGENS, ITS VALIDATION AND MAINTENANCE
}

\begin{abstract}
IHAR - PIB collection of potato viral pathogens has been maintained since 1970s. Currently there are 258 isolates in the collection representing 12 potato viruses, named PVY, PVM, PVS, PLRV, PVA, PVX, PAMV, BMYV, TBRV, AMV, CMV and TRV. The viruses are maintained in potato plants in vivo in the greenhouse (246 isolates), in potato plantlets cultured in vitro (12 isolates), in frozen leaves (two copies each of the 246 isolates) and in freeze-dried tissue (234 isolates).
\end{abstract}

Keywords: potato viruses, in vitro plantlets, freeze-dried leaves, frozen leaves

\section{INTRODUCTION}

The maintenance of a virus and keeping its variability is a fundamental requirement for various purposes: virus diagnostics (e.g. antibody production), virology study (e.g. virus population, strain identification, virus-host interaction), and potato breeding for virus resistance.

The Agriculture Research Service's (ARS) Schultz Potato Virus Collection in the United States started in 1916 (Webb, 1958; Weaver-Missick, 2000). A plant virus collection at Plant Research International (PRI) in the Netherlands was established in 1950s (Dullenmans et al., 2011). The collection of potato viruses in Czech in Potato Research Institute in Havlíčkův Brod was founded in the 1970s and has been maintained since (www.vurv.cz/mikroorganismy/Potato\% 20Viruses.html). In Scotland, diagnosis of potato viruses has been conducted by The Science and Advice for Scottish Agriculture (SASA).

Communicated by Ewa Zimnoch-Guzowska 
In Poland, a history on plant virology studies (Kryczyński, 2010) and diseases caused by viruses in potato (Świeżyński, 1968) has been summarized. A collection of potato viral pathogens at IHAR-PIB Młochów Research Center has been maintained since 1974 (Chrzanowska et al., 1996, 2001). Currently, there are 258 isolates representing 12 potato viruses named PVY, PVM, PVS, PLRV, PVA, PVX, PAMV, BMTV, TBRV, AMV, CMV and TRV in the collection (Table 1). Some virus isolates are sequenced (Table 2).

The viruses are maintained in potato plants in vivo in the greenhouse (246 isolates), in potato plantlets cultured in vitro (12 isolates), in frozen leaves (two copies each of the 246 isolates) and in freeze-dried tissue (234 isolates) (Table 3).

The detailed methods for the validation of the presence of viruses are referred to in Yin and Michalak (2018). Briefly, the virus isolates maintained in the collection in different forms have biologically, serologically and/or molecularly confirmed identities.

Potato viruses maintained in potato plants in vivo in the greenhouse and cultured in vitro at IHAR-PIB Młochów

\begin{tabular}{|c|c|c|c|c|}
\hline \multirow{2}{*}{ Name of virus } & \multirow{2}{*}{ Abbre-viation } & \multirow{2}{*}{ Genus } & \multicolumn{2}{|c|}{ Number of isolates } \\
\hline & & & in vivo & in vitro \\
\hline Potato virus $Y$ & PVY & Potyvirus & 190 & 4 \\
\hline Potato virus $M$ & PVM & Carlavirus & 10 & \\
\hline Potato virus $S$ & PVS & Carlavirus & 13 & \\
\hline Potato leafroll virus & PLRV & Polerovirus & 7 & 2 \\
\hline Potato virus $A$ & PVA & Potyvirus & 1 & 6 \\
\hline Potato virus $X$ & PVX & Potexvirus & 2 & \\
\hline Potato aucuba mosaic virus & PAMV & Potexvirus & 3 & \\
\hline Beet mild yellowing virus & BMYV & Polerovirus & 2 & \\
\hline Tomato black ring virus & TBRV & Nepovirus & 2 & \\
\hline Alfalfa mosaic virus & AMV & Alfamovirus & 3 & \\
\hline Cucumber mosaic virus & CMV & Cucumovirus & 1 & \\
\hline Tobacco rattle virus* & TRV & Tobravirus & 12 & \\
\hline SUM & 12 & 8 & 246 & 12 \\
\hline
\end{tabular}

*: Maintained in the tobacco cv. Samsun. 
Table 2

The sequenced virus isolates of the IHAR-PIB/Mlochów collection

\begin{tabular}{|c|c|c|c|c|c|}
\hline $\begin{array}{l}\text { Name of } \\
\text { virus }\end{array}$ & Name of isolate & Strain & $\begin{array}{l}\text { NCBI GenBank } \\
\text { accession } \\
\text { number }\end{array}$ & $\begin{array}{l}\text { Whole genome } \\
\text { or partial }\end{array}$ & References \\
\hline PVY & PVY-3202 & $\mathrm{PVY}^{\mathrm{NTN}}$ & KX356068 & Whole genome & \multirow{3}{*}{ Yin et al., 2017} \\
\hline PVY & PVY-3303 & $\mathrm{PVY}^{\mathrm{Z}}$-NTN & KX356069 & Whole genome & \\
\hline PVY & PVY-3411 & $\mathrm{PVY}^{\mathrm{N}-\mathrm{Wi}_{\mathrm{i}}}$ & KX356070 & Whole genome & \\
\hline PVY & Wilga (Wi) & $P V Y^{N-W i}$ & EF558545 & Whole genome & $\begin{array}{l}\text { Kosakowski et al., } 2007 \\
\text { (unpublished) }\end{array}$ \\
\hline PVY & Ditta & $\mathrm{PVY}^{\mathrm{NTN}}$ & AJ890344 & Whole genome & \multirow{7}{*}{ Schubert et al., 2007} \\
\hline PVY & Gr99 & $\mathrm{PVY}^{\mathrm{NTN}}$ & AJ890343 & Whole genome & \\
\hline PVY & $34 / 01$ & $P V Y^{N}$ & AJ890342 & Whole genome & \\
\hline PVY & LW & $\mathrm{PVY}^{\mathrm{O}}$ & AJ890349 & Whole genome & \\
\hline PVY & $12-94$ & $\mathrm{PVY}^{\mathrm{NTN}}$ & AJ889866 & Whole genome & \\
\hline PVY & E30 & $\mathrm{PVY}^{\mathrm{NTN}}$ & HM991453 & Whole genome & \\
\hline PVY & Nysa & $\mathrm{PVY}^{\mathrm{N}}$ & FJ666337 & Whole genome & \\
\hline PVY & FrKV15 & $\begin{array}{l}\text { Atypical } \\
\text { PVY }^{N-W i}\end{array}$ & HM991454 & Whole genome & $\begin{array}{l}\text { Golnik et al., } 2010 \text { (unpub) } \\
\text { Obtained from C. Kerlan, } \\
\text { France }\end{array}$ \\
\hline PVY & YE Epo & $P V Y^{N-W i}$ & JF804800 & Partial, HC-Pro & \multirow{12}{*}{$\begin{array}{l}\text { Golnik et al., } 2016 \\
\text { (unpublished) }\end{array}$} \\
\hline PVY & YE Epo & $\mathrm{PVY}^{\mathrm{O}}$ & JF804799 & Partial, VPg & \\
\hline PVY & YE Epo & $P V Y^{N-W i}$ & JF804798 & Partial, VPg & \\
\hline PVY & YE Epo & $\mathrm{PVY}^{\mathrm{O}}$ & JF804787 & Partial, CP & \\
\hline PVY & YE Epo & $P V Y^{N-W i}$ & JF804786 & Partial, CP & \\
\hline PVY & Cou $8 / 03$ & $\mathrm{PVY}^{\mathrm{NTN}}$ & JF804780 & Partial, CP & \\
\hline PVY & $\mathrm{YC} \mathrm{Zb}$ & $\mathrm{PVY}^{\mathrm{C}}$ & JF804797 & Partial, VPg & \\
\hline PVY & $\mathrm{YC} \mathrm{Zb}$ & $\mathrm{PVY}^{\mathrm{C}}$ & JF804785 & Partial, CP & \\
\hline PVY & N-Gineke & $\mathrm{PVY}^{\mathrm{N}}$ & JF804793 & Partial, VPg & \\
\hline PVY & N-Gineke & $\mathrm{PVY}^{\mathrm{N}}$ & JF804781 & Partial, CP & \\
\hline PVY & New Zealand-N & $\mathrm{PVY}^{\mathrm{N}}$ & JF804789 & Partial & \\
\hline PVY & New Zealand-NTN & $\mathrm{PVY}^{\mathrm{NTN}}$ & JF804788 & Partial & \\
\hline PVY & $47 / 96$ & $\mathrm{PVY}^{\mathrm{NTN}}$ & KY092173 & Whole genome & \multirow{4}{*}{$\begin{array}{l}\text { Grupa and Syller 2017, } \\
\text { (unpublished) }\end{array}$} \\
\hline PVY & FrKv2 & $\mathrm{PVY}^{\mathrm{N}: \mathrm{O}}$ & KY112747 & Whole genome & \\
\hline PVY & $\mathrm{PVY}^{\mathrm{O}} \mathrm{Li}$ & $\mathrm{PVY}^{\mathrm{O}}$ & KY112748 & Whole genome & \\
\hline PVY & $\mathrm{PVY}^{\mathrm{N}-\mathrm{Wi}} \mathrm{Wy}$ & $P V Y^{N-W i}$ & KY112749 & Whole genome & \\
\hline TRV & $11 \mathrm{r} 21$ & nd & KF758790 & RNA1 & \multirow{8}{*}{ Yin et al., 2014 a, b } \\
\hline TRV & $11 \mathrm{r} 21$ & nd & KF758797 & RNA2 & \\
\hline TRV & Deb57 & nd & KF758791 & RNA1 & \\
\hline TRV & Deb57 & nd & KF758794 & RNA2 & \\
\hline TRV & Mlo7 & nd & KF758792 & RNA1 & \\
\hline TRV & Mlo7 & nd & KF758795 & RNA2 & \\
\hline TRV & Slu24 & nd & KF758793 & RNA1 & \\
\hline TRV & Slu24 & nd & KF758796 & RNA2 & \\
\hline PVM & $\mathrm{I} 38$ & nd & KJ365309 & Partial, CP & Grupa and Syller, 2016 \\
\hline
\end{tabular}


Potato viruses maintained in freeze-dried potato tissue at IHAR-PIB/Młochów

\begin{tabular}{lcccc}
\hline \multirow{2}{*}{ Virus } & \multicolumn{4}{c}{ Number of isolates in freeze-dried form } \\
\cline { 2 - 5 } & $1996-1997$ & 2003 & 2007 & 2016 \\
\hline PVY & 31 & 11 & 145 & 190 \\
PVM & & 9 & 10 \\
PVS & & 3 & 13 \\
PLRV & & 5 & 7 \\
PVA & & 2 & 1 \\
PVX & & 1 & 2 \\
PAMV & & 1 & 3 \\
BMYV & & 2 & 2 \\
TBRV & & 1 & 2 \\
AMV & 1 & 2 & 3 \\
CMV & 32 & 1 & 1 \\
TRV & & 32 & 172 & 234 \\
\hline SUM & & & \\
\hline
\end{tabular}

\section{MATERIALS AND REAGENTS}

1) Virus infected potato tubers

2) Soil mixed with peat in a proportion of $1: 2$ in trays

3) Fertilizer PG mix (14-16-18) + Micro at a concentration of $0.5-0.8 \mathrm{~kg} \times \mathrm{m}^{-3}$

4) Pots $(\varnothing=16 \mathrm{~cm})$

5) MS medium with 3\% sucrose and $0.8 \%$ agar

6) Reclosable Bag (Plast Polska 150x200 mm)

7) Falcon tube (Medlab Products, $50 \mathrm{ml}$, Cat. No 24.3050.1s)

8) Latex powder-free gloves "Protect clinic" (Semperit Technische Producte Gesellschaft)

\section{EQUIPMENT}

1) Insect-free greenhouse with natural light

2) Cold dark room $\left(4^{\circ} \mathrm{C}\right)$

3) Cold chamber $\left(6-8^{\circ} \mathrm{C}\right)$

4) Laminar flow cabinet KL-21

5) Freezer $\left(-20^{\circ} \mathrm{C}\right)$ (LIEBHERR)

6) Lyophilizing cabinet (LABCONCO, Freeze Dry/SHELL FREEZE SYSTEM, FreeZONE 18)

\section{PROCEDURE}

Maintaining viruses in potato plants in vivo in the greenhouse

1) The virus isolates are maintained in their host cultivars by replanting the infected potato tubers yearly in an insect-free greenhouse (day temp. 20 $-26^{\circ} \mathrm{C}$ and night temp. $14-16^{\circ} \mathrm{C}$, day length $16 \mathrm{~h}$ ) from May to June. 
2) The harvested tubers are stored at $4^{\circ} \mathrm{C}$ in a dark cold room.

3) The selected virus isolates are checked for their pathogenicity in the potato or other proper test plants every 3-4 years.

The isolates which have been maintained for 40 years are still infectious. In total, 246 virus isolates are maintained in potato plants in vivo in the greenhouse.

\section{Maintaining viruses in potato plantlets cultured in vitro}

1) Potato plantlets of the originally collected virus-infected cultivar are maintained an in vitro culture in an MS medium (Murashige and Skoog, 1962).

2) The tubes with plantlets are kept in a growth chamber at $20-22^{\circ} \mathrm{C}$ with a photoperiod of $16 \mathrm{~h}$ with a monthly passage to a fresh medium.

3) For long-term maintenance, the MS medium is modified with a higher percentage of sucrose $(3 \%)$.

4) The plantlets are kept at $20-22^{\circ} \mathrm{C}$ and the rooted plantlets are transferred to a cold chamber at $6-8^{\circ} \mathrm{C}$ under $1000 \mathrm{~lx}$ light intensity. Under such conditions, the plantlets may be maintained for two years without passage.

5) The detailed in vitro preservation of potato plants is referred to in Strzelczyk-Żyta (2018).

In the in vitro collection, 4 PVY isolates, 6 PVA isolates and 2 PLRV isolates have been maintained since 1990s (Zagórska and Kryszczuk, 1998).

\section{Maintaining viruses in frozen leaves}

1) Leaf tissues with characteristic symptoms are collected from 4- to 6week-old potato plants which contain the respective virus.

2) The infected leaf tissues are kept in sterile plastic bags and stored at $20^{\circ} \mathrm{C}$ in a freezer.

3) Two copies of each of the 246 isolates, which are maintained in potato plants in vivo, are parallelly stored at $-20^{\circ} \mathrm{C}$.

4) The TRV isolates are maintained in frozen tobacco leaves at $-20^{\circ} \mathrm{C}$.

\section{Maintaining viruses in freeze-dried tissues}

1) One copy of the in vivo maintained viruses is also maintained in a freeze-dried form.

2) The leaf tissues with characteristic symptoms are collected into a falcon tube from 4- to 6-week-old potato plants containing the respective viruses, and stored at $-20^{\circ} \mathrm{C}$ in a freezer.

3) Before lyophilisation the cap is removed and the tube is closed with a parafilm perforated with small holes.

4) The leaves in the tubes are freeze-dried in a lyophilizing cabinet for two days.

5) Finally, the tube containing the freeze-dried tissue is closed with the same cap and stored at $4^{\circ} \mathrm{C}$ in a cold room. 
The number of virus isolates maintained in the freeze-dried form is 234 (Table 3).

\section{ACKNOWLEDGEMENTS}

This work was financed by Polish Ministry of Agriculture and Rural Development, multiannual program "Creating the scientific basis for biological progress and the protection of plant genetic resources as source of innovation and support for sustainable agriculture and food security of the country" Task 3.1 Monitoring of changes in populations of harmful and quarantine organisms for potato.

\section{REFERENCES}

Chrzanowska M., Zarzycka H., Zimnoch-Guzowska E. 1996. Kolekcja patogenów prowadzona w Zakładzie Genetyki i Syntezy Materiałów Wyjściowych Instytutu Ziemniaka. Hodowla Roślin i Nasiennictwo 4: 8-10. (in Polish)

Chrzanowska M., Muchalski T., Zagórska H. 2001. Maintenance of a collection of the viruses and the viroid pathogenic to potato. p 14-16. In: „Monografie i Rozprawy Naukowe 10a/2001” (E. ZimnochGuzowska, J. Syller, M. Sieczka, eds.). IHAR, Radzików: 131.

Dullemans A.M., Cuperus C., Verbeek M., van der Vlugt R.A. 2011. Complete nucleotide sequence of a potato isolate of strain group C of Potato virus $Y$ from 1938. Arch. Virol. 156: 473-477.

Grupa A., Syller J. 2016. Cross protection between a naturally occurring mild isolate of Potato virus $M$ (PVM) and a more virulent isolate in Datura metel plants. J. Phytopathol. 164: 69-73.

Kryczyński S. 2010. Wirusologia roślinna. PWN, Warszawa, 375 ss. (in Polish)

Murashige T., Skoog F. 1962. A revised medium for rapid growth and bioassay with tobacco tissue culture. Physiol. Plantarum 15: 473-497.

Schubert J., Fomitcheva V., Sztangret-Wiśniewska J. 2007. Differentiation of Potato virus Y strains using improved sets of diagnostic PCR-primers. J. Virol. Methods 140: 66-74.

Strzelczyk-Zyta D. 2017. In vitro preservation of potato plants, Plant Breed Seed Sci., 76:.

Świeżyński K. 1968. Choroby wirusowe ziemniaków. Wyd. 3. PWRiL, Warszawa. (in Polish)

Weaver-Missick T. 2000. A unique potato virus collection. Agri. Res. vol. 48: 19.

Webb R.E. 1958. Schultz potato virus collection. Am. Potato J. 35: 615-619.

Yin Z., Michalak K. 2017. Diagnosis of the presence of viruses in potato and soil, Plant Breed. Seed Sci. 75:37-55

Yin Z., Pawełkowicz M., Michalak K., Chrzanowska M., Zimnoch-Guzowska E. 2014a. The genomic RNA1 and RNA2 sequences of the tobacco rattle virus isolates found in Polish potato fields. Virus Res. 185: 110-113.

Yin Z., Pawełkowicz M., Michalak K., Chrzanowska M., Zimnoch-Guzowska E. 2014b. Single-nucleotide polymorphisms and reading frame shifts in RNA2 recombinant regions of tobacco rattle virus isolates Slu24 and Deb57. Arch. Virol. 159: 3119-3123.

Yin Z., Xie F., Michalak K., Pawełkowicz M., Zhang B., Murawska Z., Lebecka R., Zimnoch-Guzowska E. 2017. Potato cultivar Etola exhibits hypersensitive resistance to PVY ${ }^{\mathrm{NTN}}$ and partial resistance to PVYZ ${ }^{-N T N}$ and $\mathrm{PVY}^{\mathrm{N}-\mathrm{Wi}}$ strains and strain-specific alterations of certain host miRNAs might correlate with symptom severity. Plant Pathol. 66: 539-550.

Zagórska H., Kryszczuk A. 1998. Kolekcja form diploidalnych i tetraploidalnych ziemniaka w IHAR - Oddział Młochów. II. Kolekcja in vitro. Materiały z I Ogólnopolskiej Konferencji.: Zasoby genowe roślin użytkowych - gromadzenie, ocena i wykorzystanie, Puławy: 62. (in Polish) 